\title{
Is South Asia an Optimum Currency Area?
}

\author{
Biswash Gauchan \\ Mittal School of Business, Lovely Professional Universiy, Phagwara, Punjab, India \\ Vishal Sarin \\ Mittal School of Business, Lovely Professional Universiy, Phagwara, Punjab, India
}

\begin{abstract}
We assess whether the South Asian Association of Regional Cooperation is an Optimum Currency Area by analyzing the symmetry of structural shocks. The result shows that SAARC countries experience asymmetric patterns of shocks, which implies the region is not yet ready for a common currency. However, we also find the increased number of positive correlation such as GDP growth, inflation, exchange rates movements and supply shocks compared to the results in the previous studies. Thus, macroeconomic convergence is ongoing among the countries, which can underpin the basis for greater monetary cooperation.
\end{abstract}

JEL Classification: E42, F15, F33, F36, N15

Keywords: South Asia, SVAR, Monetary integration

\footnotetext{
* Corresponding Author: Biswash Gauchan; Mittal School of Business, Lovely Professional University, Jalandhar - Delhi G.T. Road, Phagwara, Punjab, India, Tel: 1824444213, Fax: 1824506111, E-mail: biswas.gauchan@gmail.com

Co-author: Vishal Sarin; ; Mittal School of Business, Lovely Professional University, Jalandhar - Delhi G.T. Road, Phagwara, Punjab, India, Tel: 1824444213, Fax: 1824506111, E-mail: vishal.sarin@lpu.co.in 


\section{Introduction}

The successful launch of Euro in 1999 has attracted the worldwide attention on monetary union with a common currency. Many regional economic blocks contemplated having similar monetary arrangements for economic development. The South Asian Association of Regional Cooperation (SAARC) founded in 1985 with seven members was not an exception. On the recommendation of the Group of Eminent Persons (GEP) with representation from all the member countries, the $11^{\text {th }}$ SAARC summit was held at Kathmandu in January 2002. It adopted the vision of setting up South Asian Customs Union (SACU) by 2015 and South Asian Economic Union (SAEU) by 2020 with a possibility of monetary union with common currency (SAARC 1997,1998).

South Asia is home to nearly one fourth of world population but accounts for only 3.81 percent of global nominal GDP and 2.52 percent of global international trade (WDI 2017). Tables 1 to 3 present some important statistics of the SAARC and its members. Table 1 highlights the asymmetries among the member in terms of the size, population, output, trade, etc. SAARC's intra-regional trade is limited to 5.8 percent in 2016 as shown in Table 2. India, in particular, accounts for 77 percent of region's international trade but trades less than 3 percent within the region. However, for smaller member countries such as Nepal, Bhutan and Afghanistan, the intra-regional trade contributes significantly to their respective international trade. Table 3 shows different currency regimes and monetary frameworks of SAARC countries in 2016.

The objective of this study is to examine whether the SAARC is an Optimum Currency Area (OCA). In OCA, member countries maintain fixed exchange rate or adopt a single currency, which can reduce transaction costs and eliminate exchange rate volatility. However, once a country becomes a member of an OCA, it loses autonomy of monetary policy and exchange rate management. When the economies in an OCA face similar nature of shocks, they can respond by adopting uniform policy. However, if the economies in the OCA are structurally different from each other and experience different nature of shocks, uniform policy may not be appropriate to address country specific disturbances. Hence, identifying the nature of shocks and finding their symmetry across the area is a key to assess whether the countries in the 


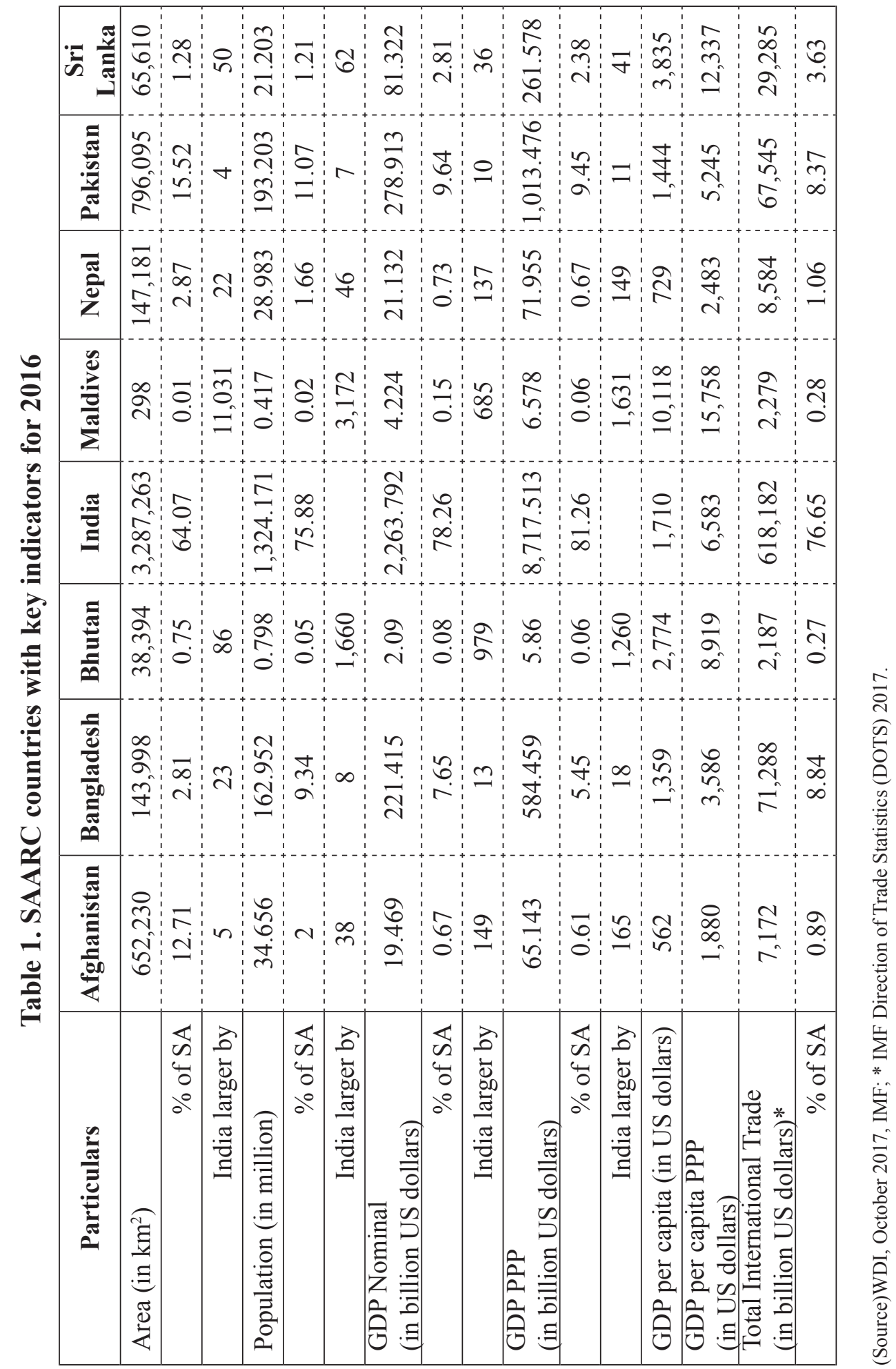


Table 2. SAARC trade on merchandise

\begin{tabular}{|l|c|c|c|c|c|}
\hline \multicolumn{1}{|c|}{ Trade } & $\mathbf{2 0 1 2}$ & $\mathbf{2 0 1 3}$ & $\mathbf{2 0 1 4}$ & $\mathbf{2 0 1 5}$ & $\mathbf{2 0 1 6}$ \\
\hline Import from World & 599.224 & 585.133 & 587.467 & 508.785 & 482.046 \\
\hline Export to World & 356.216 & 379.261 & 383.753 & 330.061 & 324.476 \\
\hline $\begin{array}{l}\text { Total International } \\
\text { Trade }\end{array}$ & 955.440 & 964.395 & 971.220 & 838.846 & 806.523 \\
\hline Intra-regional Export & 21.149 & 22.667 & 26.578 & 23.778 & 22.573 \\
\hline Intra-regional Import & 19.891 & 20.535 & 24.172 & 23.412 & 24.172 \\
\hline $\begin{array}{l}\text { Total Intra-regional } \\
\text { Trade }\end{array}$ & 41.040 & 43.202 & 50.749 & 47.190 & 46.746 \\
\hline $\begin{array}{l}\text { SAARC Intra- } \\
\text { regional Trade \% }\end{array}$ & $4.30 \%$ & $4.48 \%$ & $5.23 \%$ & $5.63 \%$ & $5.80 \%$ \\
\hline
\end{tabular}

(Source) IMF Direction of Trade Statistics (DOTS) 2017

Table 3. Currency Regime of SAARC Countries

\begin{tabular}{|c|c|c|c|}
\hline Country & $\begin{array}{c}\text { Name of Currency } \\
\text { (Symbol) }\end{array}$ & Regime & $\begin{array}{c}\text { Monetary } \\
\text { Framework }\end{array}$ \\
\hline Afghanistan & $\begin{array}{l}\text { Afghani } \\
\text { (AFA) }\end{array}$ & Floating & $\begin{array}{c}\text { Monetary } \\
\text { aggregate target }\end{array}$ \\
\hline Bangladesh & $\begin{array}{l}\text { Bangladesh Taka } \\
\text { (BDT) }\end{array}$ & Stabilized arrangement & $\begin{array}{l}\text { Monetary } \\
\text { aggregate target* }\end{array}$ \\
\hline Bhutan & $\begin{array}{l}\text { Bhutanese Ngultrum } \\
\text { (BTN) }\end{array}$ & $\begin{array}{l}\text { Conventional Peg } \\
\text { (Fixed with INR at party) }\end{array}$ & $\begin{array}{l}\text { Exchange rate } \\
\text { anchor }\end{array}$ \\
\hline India & $\begin{array}{l}\text { Indian Rupee } \\
\text { (INR) }\end{array}$ & Floating & Inflation Targeting \\
\hline Maldives & $\begin{array}{l}\text { Rufiyaa } \\
\text { (MVR) }\end{array}$ & $\begin{array}{c}\text { Stabilized arrangement } \\
\text { (Fixed with USD at } \\
1 \text { USD }=12.85+20 \% \text { MVR) }\end{array}$ & $\begin{array}{c}\text { Exchange rate } \\
\text { anchor }\end{array}$ \\
\hline Nepal & $\begin{array}{l}\text { Nepali Rupee } \\
\text { (NPR) }\end{array}$ & $\begin{array}{l}\text { Conventional Peg } \\
\text { (Fixed with INR at } \\
1 \text { INR }=1.6 \text { NPR) }\end{array}$ & $\begin{array}{c}\text { Exchange rate } \\
\text { anchor }\end{array}$ \\
\hline Pakistan & $\begin{array}{l}\text { Pakistan Rupee } \\
\text { (PKR) }\end{array}$ & $\begin{array}{c}\text { Other Managed } \\
\text { arrangement }\end{array}$ & Other** \\
\hline Sri Lanka & $\begin{array}{c}\text { Sri Lankan Rupee } \\
\text { (LKR) }\end{array}$ & $\begin{array}{l}\text { Crawl-like } \\
\text { arrangement }\end{array}$ & Other** \\
\hline
\end{tabular}

(Source) IMF Annual Report on Exchange Arrangement and Exchange Restrictions (AREAER) 2016

* Bangladesh maintains de facto exchange rate anchor with US dollar

** Other includes those with no specific monetary framework for the conduct of monetary policy 
area are suitable candidates for OCA.

For the empirical analysis a Structural Vector Auto Regression (SVAR) approach is used. The structural shocks are classified into supply shocks and demand shocks which are extracted from the SVAR process with two variables, output growth and inflation. We then pair countries and estimate their correlations of structural shocks.

We find that although the proportion of positive correlations increases for both supply and demand shocks compared to the past literatures, only few correlations are significant and positive, which implies that members of SAARC are mostly experiencing different shocks. The analysis of simple correlations of key macroeconomic variables such as GDP growth, inflation and nominal exchange rate between countries also indicates similar results. Findings suggest that SAARC is not an OCA.

The remaining of the paper is organized as follows. Section $I$ briefly reviews the literature .Section III provides methodology and Section IV reports the estimation results using the SVAR approach. Section V discusses the results and section VI concludes.

\section{Literature}

Mundell (1961) propounds the theory of OCA and McKinnon (1963) adds openness to the literature, which argues that as economy moves from closed economy to open economy, flexible exchange rate would diminish internal price stability and external imbalance, and thus OCA is more appropriate to open economy. Kenen (1969) brings diversification in production and consumption. The more the economy is diversified, the less it needs to rely on exchange rate adjustment to address external imbalance. Similarly, Ingram (1962) considers financial integration based on the idea that the imbalance caused by trade can be addressed through transfer of capital from surplus region to deficit region, which is only possible for economies with high level of financial integration. Fleming (1971) notes that low and similar level of inflation rates help in smoothing the terms of trade which results in less adjusting exchange rate. Tower and Willett (1976) states that similar preference over unemployment, growth, inflation and ability of the authorities is crucial for a successful OCA. 
The first generation literatures mostly revolved around defining criteria for OCA which are ex ante requisites. The subsequent literatures highlight the ex post or endogenous nature of those criteria. Empirical studies have shown the evidences of how a monetary union with a common currency led to higher level of trade, capital flows, financial integration, and factor mobility in the subsequent periods with the violation of those ex ante prerequisites (Frankel and Rose 1998). Kenen and Meade (2008) asserts that the consolidation of currencies provides gains both in efficiency and credibility. The efficiency gain arises from greater price transparency, elimination of currency conversion and exchange rate risk. European Commission (1990) estimates that the cost saved from elimination of currency conversion among EU countries to be as big as 0.4 percent of GNP. The currency union also provides credibility gain to the countries which have persistent inflation, high fiscal deficit and where the independence of central bank is consistently compromised.

There are several empirical studies that show a monetary integration results in varying degree of increases in trade and investment. The most notable works are Rose A. (2000a, 2000b, 2004). They show that countries with common currency trade about three times more than countries without it. While the increase in trade have been confirmed by many studies, the magnitude of common currency effect varies from study to study (Micco et al. 2003, Frankel and Rose 2002).

Efficiency and credibility gains are not only limited to goods markets but also extended to asset markets. Monetary integration has led to the convergence of long-term interest rate in EU between the peripheral and the central economies from the highs of 3 to 4 percent difference in the mid1990s (Kenen and Meade 2008).

However, very little has been said and written about economic and monetary integration of South Asia largely due to slow progress towards regional economic integration and insignificance of the region on the global economy. The limelight in Asia economic integration mainly revolves around East and Southeast Asia such as ASEAN or ASEAN plus 1. For example, paper of Eichengreen and Bayoumi(1999) on whether Asia is an OCA is limited to East and Southeast Asia. When Mundell was writing about the prospects of Asian currency area, he was referring to East and Southeast Asia (Mundell 2003). Saxena (2003) goes further by proposing an OCA of ASEAN 
plus 4 (Japan, China, South Korea and India).

Some studies have suggested that South Asia is not an OCA (Maskay 2001, 2003, Jayasuriya et al. 2005) because the countries are subject to asymmetric output disturbances. On the other hand, Saxena (2005) postulates that South Asia would benefit more by adopting a common currency based on the analysis of the co-movement of patterns of structural shocks and the potential normalization of bilateral relations between India and Pakistan that monetary union would likely to foster.

\section{Methodology and Data}

The most widely used technique in the OCA literature is a SVAR approach. Blanchard and Quah (1989) utilizes it to assess dynamic effects of shocks on macroeconomic variables. Bayoumi (1992) extends it to measure the impacts of Exchange Rate Mechanism (ERM) on patterns of shocks that European Monetary System (EMS) was facing. However Bayoumi and Eichengreen $(1993,1994)$ are the first to employ the SVAR to analyze OCA by considering and comparing countries of Europe and regions within the US, and countries of Western Europe, East Asia and Americas.

The Over-Identification Condition (OIC) of a SVAR is to consider one set of shocks to have long run impact on both macroeconomic variables (output and inflation) and the second set of shocks to have long run impact on only one variable (inflation). The former is termed as supply shocks and the latter is termed as demand shocks. Given that the impact of demand shocks on output is temporary, the output will eventually return to its long run equilibrium position according to the Aggregate Demand - Aggregate Supply (AD-AS) model. Even if both employment and output level rise in the short run, sticky wage would cause a decrease in real wage. But in the long run the output returns to its long term full employment equilibrium level once the real wage is adjusted accordingly to the price changes. This depicts upward sloping short run aggregate supply curve and vertical long run aggregate supply curve. On the contrary, both short and long run aggregate demand curves are downward sloping signifying that lower prices boost higher demand both in the short and long run. The permanent supply shocks such as technological innovation would permanently shift the long run full 
employment output to new equilibrium: increase in output and decrease in price level. On the other hand, the permanent shock to aggregate demand would have only short run impact on the output which eventually return to its long run equilibrium level once the real wage is adjusted properly. This OIC is necessary to estimate two different types of shocks as explained in the following paragraphs.

Consider a system with infinite Moving Average (MA) of variables of vector $X$ with equal number of shocks $\varepsilon$ and a lagged operator $L$. The model can be represented as:

$$
X_{t}=A_{0} \varepsilon_{t}+A_{1} \varepsilon_{t-1}+A_{2} \varepsilon_{t-2}+\cdots=\sum_{i=0}^{\infty} L^{i} A_{i} \varepsilon_{t}
$$

where the matrix $A_{i}$ denotes the impulse response functions of shocks $\varepsilon_{t}$ to the variable $X$ which represents a pair of macroeconomic variables, i.e., change in output and change in price. The above equation can be presented in the following matrix form:

$$
\left[\begin{array}{l}
\Delta y_{t} \\
\Delta p_{t}
\end{array}\right]=\sum_{i=0}^{\infty} L^{i}\left[\begin{array}{ll}
a_{11 i} & a_{12 i} \\
a_{21 i} & a_{22 i}
\end{array}\right]\left[\begin{array}{l}
\varepsilon_{s t} \\
\varepsilon_{d t}
\end{array}\right]
$$

where $\Delta y_{t}$ and $\Delta p_{t}$ represent the change in the logarithm of output and inflation, $\varepsilon_{s t}$ and $\varepsilon_{d t}$ denote the supply shocks and demand shocks respectively. $a_{11 i}$ denotes elements of matrix $A_{i}$. The shocks are assumed to be independent of each other, that is, they have completely different underlying causes. For example, demand shocks can be the outcome of monetary policy whereas supply shocks are caused by technological innovation. However, when the causes of both shocks happen to originate from same source or similar events such as changes in the commodity price for those countries that are heavily dependent on its exports, the assumption will fail and methodology will become redundant. Given the assumption that demand shock has only temporary or short term effect on the output, the cumulative net effect of the demand shock on output would be zero and therefore can be written as: 


$$
\sum_{i=0}^{\infty} a_{12 i}=0
$$

The infinite MA process of Equation (1) can be represented as autoregressive process by inverting the MA operator because elements of $X$ are covariance stationary. Hence, the above equations can be solved by using a VAR where all the variables of $X_{t}$ are regressed upon their lagged values The equation takes the following form where $B$ denotes the coefficient of the lagged variables and $e_{t}$ represents error terms or residuals from VAR process:

$$
\begin{aligned}
X_{t} & =B_{1} X_{t-1}+B_{2} X_{t-2}+\cdots+B_{n} X_{t-n}+e_{t} \\
& =[I-B(L)]^{-1} e_{t} \\
& =\left[I+B(L)+B(L)^{2}+\cdots\right] e_{t} \\
& =e_{t}+D_{1} e_{t-1}+D_{2} e_{t-2}+\cdots
\end{aligned}
$$

In the Equation (4), $e_{t}$ can be labeled as $e_{y t}$ and $e_{p t}$ to represent residuals of the lagged values of change in output and inflation respectively. The residuals $e_{t}$ in the Equation (4) can be transformed into shocks $\varepsilon_{t}$ in the Equations (1) and (2) with $e_{t=} C_{\varepsilon t}$ where $C$ is a matrix of coefficient of shocks. In a two-bytwo case, four restrictions are needed to identify the matrix $C$. Two of them are derived from normalization by setting variance of shocks $\varepsilon_{y t}$ and $\varepsilon_{p t}$ equal to unity. Third restriction comes from the assumption that supply and demand shocks are independent and the last restriction comes from the assumption that demand shocks have only short term effects on output. These allow the matrix $C$ to be uniquely identified so that supply and demand shocks can be determined. The final equation in VAR form is presented as follows:

$$
\sum_{i=0}^{\infty}\left[\begin{array}{ll}
d_{11 i} & d_{12 i} \\
d_{21 i} & d_{22 i}
\end{array}\right]\left[\begin{array}{ll}
c_{11 i} & c_{12 i} \\
c_{21 i} & c_{22 i}
\end{array}\right]=\left[\begin{array}{ll}
\cdot & 0 \\
. & .
\end{array}\right]
$$

However, it is arbitrary to separate the disturbance into the two variable: change in output as supply shock and inflation as demand shock. The assumptions that supply shock has permanent impact on output and demand 
shock has only temporary impact on output, do not hold under many situations. The methodology therefore comes in handy when one validates the impact of shocks on price only under the imposed restrictions pertains to impact on output. According to the AS-AD model, the outcomes are examined to confirm whether positive supply shocks reduce price and positive demand shocks increase price.

After estimating demand shocks and supply shocks from the above methodology, countries are paired and their correlation of each shock is evaluated to determine the synchronization of shocks. Positive and significant coefficient of correlation means that the paired countries share similar nature of shocks and thus suitable for common currency or greater monetary integration. On the contrary, negative or statistically insignificant coefficient of correlation implies that the countries are not suitable for an OCI.

The other important dimensions are size of the disturbances and speed of adjustment. Larger size of disturbances could affect more on the economy than small one, which would require a country specific policy. Similarly, the slower speed of adjustment to a shock would entail elongated disequilibrium in the economy in the absence of targeted policy measures. Thus large disturbances and slow adjustment may weaken the uniform policy of OCI. The size of the disturbance relating to supply shock is measured as long run impact on output while that of demand shock is estimated as the sum of the first year's impact on output and price, that is, nominal output with the impulse response function. Change in price is not factored in during estimating the size of disturbance caused by supply shock because the identification restriction assumes no change in price in the long run. The speed of adjustment is measured as the proportion of response after two years to the long run effect (Bayoumi and Eichengreen 1994). Furthermore, the variance decomposition analysis helps in finding relative importance of different types of shocks in explaining the changes of the variables across different time horizons. If the changes in the macroeconomic variables stems largely from similar shocks across the countries, the region could be good candidate for a common currency.

The statistical significance of correlation coefficient is determined by a statistic $\ln (1+r)(1-r) / 2$ where $r$ is the sample correlation coefficient and has an asymptotically normal distribution with a variance of $N-3$ where $N$ is the 
number of observations ${ }^{1}$ (Romano 1970). For the analysis of the correlation of output growth, inflation and nominal exchange rate, we use 25 observations and for shocks the total observations are 24 under single lag and 23 under two lags respectively. Hence, the correlation coefficients above $0.395,0.403$ and 0.412 are significant at 5 percent level for 25, 24 and 23 observations respectively. Similarly, the coefficients above $0.337,0.344$ and 0.352 are significant at 10 percent for 25, 24 and 23 observations respectively.

Data covers the period of 1991 2015. The choice of the year 1991 is particularly important because India, the central economy of South Asia, initiated its major economic reforms by opening up its economy from that year in the middle of foreign exchange reserve crisis. The data are sourced from World Economic Outlook (WEO) October 2016, IMF unless mentioned otherwise. Afghanistan which joined SAARC in 2007 is excluded because the lack of adequate data. Time-varying perspectives are considered when comparing our results with past studies (Maskey 2003, Saxena 2005) which follow similar methodologies.

\section{Estimation and Empirical Results}

\section{A. Simple correlation of variables}

The analysis begins by observing simple correlation of real output growth (percentage change in real GDP) as presented in table 4. At 5 percent level of significance, the only statistically significant correlation is the one between India and Bangladesh. The correlation between Bangladesh and Bhutan is significant at 10 percent level. Nepal holds negative correlation with the highest number of countries (four) followed by India (two). On the other hand, Maldives doesn't have negative correlation with any of the countries. The rest four countries have negative correlation with only one country. The mean growth rate ranges from 4.36 for Pakistan to 7.34 for Maldives. Standard deviation is very high for Maldives at 6.67 while the lowest for Bangladesh at 0.79. Overall, there is very little co-movement of output growth that is statistically significant despite 67 percent of the coefficients

${ }^{1}$ Formula: $\mathrm{z}=\frac{1}{2} \sqrt{(N-3)\left\{\ln \frac{(1+r)(1-\beta)}{(1-r)(1+\beta)}\right.}$ is used to test the significance of correlations with $\mathrm{H}_{0}: \beta=0 ; \mathrm{H}_{1}: \beta \neq 0$ using $\alpha=0.10,0.05$. 
show positive correlation. When comparing the results with Maskay (2003) for the period of 1980 2000 and Saxena (2005) for the period 1971 2003, no specific pattern of convergence in output growth is found at significant level but the number of positive correlation has increased from 43 percent and 52 percent respectively to 76 percent.

Table 4. Pairwise correlation of GDP growth

\begin{tabular}{|l|c|c|c|c|c|c|c|}
\hline \multicolumn{1}{|c|}{ Country } & $\begin{array}{c}\text { Bangla- } \\
\text { desh }\end{array}$ & Bhutan & India & Maldives & Nepal & Pakistan & $\begin{array}{c}\text { Sri } \\
\text { Lanka }\end{array}$ \\
\hline Bangladesh & 1.00 & & & & & & \\
\hline Bhutan & $0.39 *$ & 1.00 & & & & & \\
\hline India & $0.59 * *$ & 0.23 & 1.00 & & & & \\
\hline Maldives & 0.08 & 0.30 & 0.02 & 1.00 & & & \\
\hline Nepal & -0.25 & -0.33 & -0.22 & 0.01 & 1.00 & & \\
\hline Pakistan & 0.21 & 0.00 & 0.22 & 0.13 & -0.02 & 1.00 & \\
\hline Sri Lanka & 0.12 & 0.15 & -0.04 & 0.14 & 0.29 & 0.05 & 1.00 \\
\hline Mean & 5.56 & 6.52 & 6.60 & 7.34 & 4.45 & 4.36 & 5.73 \\
\hline Std. Dev. & 0.79 & 2.59 & 2.22 & 6.67 & 1.57 & 1.96 & 3.81 \\
\hline
\end{tabular}

(Note) $* *$ and $*$ represent significance at 5 percent and 10 percent levels respectively.

On the inflation front, measured as percentage change in GDP Deflator, one third of the correlations are statistically significant as shown in Table 5. Maldives leads the group with the highest number of significant correlations with four countries followed by India and Nepal with three countries each and Bhutan and Pakistan with two countries each. None of inflation correlation of Bangladesh and Sri Lanka is significantly different from zero. At 10 percent level of significance, the correlation coefficients of Pakistan with both Bangladesh and India is significant. Sri Lanka shows the highest mean inflation at 9.82 percent and Bangladesh exhibits the lowest at 5.07 percent. The standard deviation is the lowest for Bangladesh at 1.91 and the highest for Maldives at 5.76. Similar to the results of Maskay (2003) and Saxena (2005), 72 percent of the total correlation of inflation is positive. For output growth, the number of statistically significant correlation coefficients 
is higher while the number of positive correlations is almost the same. In the absence of sizable number of statistically significant correlations, it is difficult to establish a specific region wide relationship.

Table 5. Pairwise correlation of inflation

\begin{tabular}{|l|c|c|c|c|c|c|c|}
\hline \multicolumn{1}{|c|}{ Country } & $\begin{array}{c}\text { Bangla- } \\
\text { desh }\end{array}$ & Bhutan & India & Maldives & Nepal & $\begin{array}{c}\text { Paki- } \\
\text { stan }\end{array}$ & $\begin{array}{c}\text { Sri } \\
\text { Lanka }\end{array}$ \\
\hline Bangladesh & 1.00 & & & & & & \\
\hline Bhutan & -0.07 & 1.00 & & & & & \\
\hline India & 0.07 & $0.48^{* *}$ & 1.00 & & & & \\
\hline Maldives & 0.07 & $0.40^{* *}$ & $0.62^{* *}$ & 1 & 1.00 & & \\
\hline Nepal & 0.07 & 0.17 & $0.42^{* *}$ & $0.46^{* *}$ & 1.00 & & \\
\hline Pakistan & $0.38^{*}$ & 0.22 & $0.38^{*}$ & $0.61 * *$ & $0.56^{* *}$ & 1.00 & \\
\hline Sri Lanka & -0.01 & -0.06 & 0.04 & -0.01 & -0.01 & -0.08 & 1.00 \\
\hline Mean & 0.0507 & 0.0687 & 0.0705 & 0.0639 & 0.0886 & 0.0854 & 0.0982 \\
\hline Std. Dev. & 0.0191 & 0.0233 & 0.0270 & 0.0576 & 0.0441 & 0.0440 & 0.0487 \\
\hline
\end{tabular}

(Note) $* *$ and $*$ represent significance at 5 percent and 10 percent levels respectively.

The results of correlation of changes in nominal exchange rate, provided in table 6 , corresponds with the exchange rate regimes that member countries have adopted. High significant correlations among India and Bhutan as well as India and Nepal stem from fixed exchange rate mechanism that exists between them. Any country that has significant correlation with India, for example Pakistan, also has significant correlation with both Bhutan and Nepal. The correlation between Bangladesh and Sri Lanka is also significant because both adopt stabilized exchange rate around US dollar. Maldives follows a fixed exchange rate mechanism with US dollar therefore its correlations with all the other countries are insignificant. Further, it is the only country with negative coefficient with Pakistan and Sri Lanka while rest of all the correlations is positive. To recap, the currencies in the region have moved together in the same direction (over 90 percent). But similar to correlation of inflation, the number of significant relationship of the changes in exchange rate is only 7 out of 21 pairs of countries, which suggests that there is no 
statistically significant regional level co-movement.

Table 6. Pairwise correlation of changes in nominal exchange rate

\begin{tabular}{|l|c|c|c|c|c|c|c|}
\hline \multicolumn{1}{|c|}{ Country } & $\begin{array}{c}\text { Bangla- } \\
\text { desh }\end{array}$ & Bhutan & India & Maldives & Nepal & Pakistan & $\begin{array}{c}\text { Sri } \\
\text { Lanka }\end{array}$ \\
\hline Bangladesh & 1.00 & & & & & & \\
\hline Bhutan & 0.24 & 1.00 & & & & & \\
\hline India & 0.24 & $1.00 *$ & 1.00 & & & & \\
\hline Maldives & $0.35^{*}$ & 0.31 & 0.31 & 1.00 & & & \\
\hline Nepal & 0.24 & $0.99 *$ & $0.99^{* *}$ & 0.28 & 1.00 & & \\
\hline Pakistan & 0.08 & $0.49 *$ & 0.49 & -0.06 & $0.46^{* *}$ & 1.00 & \\
\hline Sri Lanka & $0.45^{* *}$ & 0.33 & 0.33 & -0.02 & $0.34^{*}$ & $0.38^{*}$ & 1.00 \\
\hline
\end{tabular}

(Note) $* *$ and $*$ represent significance at 5 percent and 10 percent levels respectively.

\section{B. Correlation of structural shocks}

Tables 7 and 8 exhibit correlation matrix of supply shocks following one lag and two lags processes respectively. Under the one lag process, Bangladesh and India share symmetric supply shocks significant at 5 percent level while Sri Lanka and Bangladesh shares it significant at 10 percent level. Other than these two, none of the other correlation coefficients are significant, which means the region is not subject to symmetric supply shocks. Going by the sign of the correlation, 71 percent of total correlation coefficients are positive. The coefficient of correlation ranges between the lowest -0.2556 (between Bhutan and Nepal) and the highest 0.4939 (between Bangladesh and India).

In the two lags process, the number of positive correlation of supply shocks comes down to 57 percent while the number of significant correlation is only one, between Bangladesh and India, at 5 percent level. However, at 10 percent level, the number of statistically significant correlation increased by two: between Maldives and Pakistan, Pakistan and Sri Lanka. In comparison to Saxena (2005), there is indeed some improvement in the number of positive correlations which was barely one third under two lags process. The 
negative significant correlations between Bangladesh and Maldives as well as Bangladesh and Pakistan turn into positive correlations. Despite growing number of positive symmetries of supply shocks in the new millennium, only one correlation is statistically significant among 21 pairs, which again suggests that the region is subject to asymmetric structural shocks. The coefficient of correlation ranges from the lowest -0.2247 between Nepal and Pakistan to the highest 0.4249 between Bangladesh and India.

Under lag one process, Nepal shows the largest number of negative correlation of supply shocks. Pakistan and Sri Lanka face negative correlations with two countries while remaining four countries show negative correlation with one country. Under two lags process, Nepal still continues to show the largest number of negative correlations while Pakistan faces negative correlation with the least number of countries. Maldives and Sri Lanka share negative correlations with three countries while Bhutan, India and Bangladesh share negative correlations with two countries.

Table 7. Pairwise correlation of supply shocks

\begin{tabular}{|l|c|c|c|c|c|c|c|}
\hline Country & $\begin{array}{c}\text { Bangla- } \\
\text { desh }\end{array}$ & Bhutan & India & Maldives & Nepal & Pakistan & $\begin{array}{c}\text { Sri } \\
\text { Lanka }\end{array}$ \\
\hline $\begin{array}{l}\text { Bangla- } \\
\text { desh }\end{array}$ & 1 & & & & & & \\
\hline Bhutan & 0.1339 & 1 & & & & & \\
\hline India & $0.4939 * *$ & 0.1728 & 1 & & & & \\
\hline Maldives & 0.2731 & 0.2878 & 0.0481 & 1 & & & \\
\hline Nepal & -0.1938 & -0.2556 & 0.0302 & -0.1175 & 1 & & \\
\hline Pakistan & 0.2525 & 0.0766 & 0.2856 & 0.2144 & -0.0035 & 1 & \\
\hline Sri Lanka & $0.3584 *$ & 0.1425 & -0.0040 & 0.1239 & 0.0998 & -0.0270 & 1 \\
\hline Range & 3.3459 & 4.249 & 3.4808 & 4.6526 & 4.3393 & 3.8274 & 3.7840 \\
\hline Minimum & -1.7590 & -1.953 & -1.6392 & -2.2386 & -2.5375 & -2.0237 & -2.1187 \\
\hline Maximum & 1.5870 & 2.297 & 1.8415 & 2.4140 & 1.8018 & 1.8037 & 1.6653 \\
\hline
\end{tabular}

(Note) $* *$ and $*$ represent significance at 5 percent and 10 percent levels respectively. 
Table 8. Pairwise correlation of supply shocks

\begin{tabular}{|l|c|c|c|c|c|c|c|}
\hline \multicolumn{1}{|c|}{ Country } & $\begin{array}{c}\text { Bangla- } \\
\text { desh }\end{array}$ & Bhutan & India & Maldives & Nepal & Pakistan & $\begin{array}{c}\text { Sri } \\
\text { Lanka }\end{array}$ \\
\hline $\begin{array}{l}\text { Bangla- } \\
\text { desh }\end{array}$ & 1 & & & & & & \\
\hline Bhutan & -0.0223 & 1 & & & & & \\
\hline India & $0.4249 * *$ & 0.2617 & 1 & & & & \\
\hline Maldives & 0.0723 & 0.1765 & -0.0770 & 1 & & & \\
\hline Nepal & -0.0992 & -0.0833 & 0.2257 & -0.0678 & 1 & & \\
\hline Pakistan & 0.1048 & 0.2947 & 0.1006 & $0.3555 *$ & -0.2247 & 1 & \\
\hline Sri Lanka & 0.1690 & -0.0785 & -0.0676 & 0.0905 & -0.1027 & $0.3937 *$ & 1 \\
\hline Range & 3.222 & 3.864 & 3.494 & 3.758 & 3.581 & 4.357 & 3.386 \\
\hline Minimum & -1.771 & -1.736 & -1.849 & -1.617 & -2.021 & -2.895 & -1.871 \\
\hline Maximum & 1.451 & 2.128 & 1.645 & 2.142 & 1.560 & 1.462 & 1.515 \\
\hline
\end{tabular}

(Note) $* *$ and $*$ represent significance at 5 percent and 10 percent levels respectively.

Table 9 and 10 exhibit correlations of demand shocks under one lag one and two lags processes respectively. Under lag one process, the coefficients of correlation between Bangladesh and Bhutan, India and Bangladesh, Sri Lanka and India as well as Maldives and Pakistan are statistically significant. At 10 percent level, the correlation between India and Sri Lanka is also significant. Two third of total correlations are positive. The coefficient of correlation ranges from the lowest -0.3293 between Bangladesh and Nepal to the highest 0.5360 between Maldives and Pakistan.

Moving from one lag one to two lags process, the number of positive correlation remains exactly the same though the pairs that shows positive correlation are changed. The number of statistically significant coefficients decreases from three to two. The correlation between Bangladesh and Bhutan is significant at 10 percent level, which is significant at 5 percent level on the one lag process while the correlation between India and Sri Lanka is significant at 5 percent level, which is significant at 10 percent level on the one lag process. Similarly, the significant correlation between Maldives and Pakistan under one lag process become insignificant under two lags process. Comparing with the results of Saxena (2005), the number of 
positive correlations is indeed dropped from 81 percent to 67 percent. So is the number of statistically significant correlations, from four to two. Despite of the fact that two third correlations are positive, the symmetry of shock is not different from zero since there are only two statistically significant correlations out of 21 pairs under lag two process, which suggests that the region is not an OCA even from the perspective of demand shock. Nepal and Bhutan show the largest number of negative correlation with three countries each, while Bangladesh faces the least number of negative correlation with Nepal only. Other four countries present two negative correlations respectively. Interestingly, Saxena (2005) shows that Nepal and Pakistan have positive correlations with all the countries half of which are statistically significant. The coefficient of correlation ranges from the lowest -0.3362 between Nepal and Sri Lanka to the highest 0.4736 between Bangladesh and India.

The results clearly point to the asymmetries of structural shocks across the countries. Although both the correlations of supply shocks and demand shocks show high proportion of positive correlations, they are statistically insignificant. Trends of correlations are also mixed. There is increase in the proportion of positive correlations of supply shocks while the proportion of positive correlations of demand shocks decrease. Technically, analysis of supply shocks provides more robust basis for evaluating OCA because demand shocks are considered to be the outcome of the policy measures. By adopting uniform policy across the monetary union, the asymmetry of demand shocks will be largely taken care of. 
Table 9. Pairwise correlation of demand shocks

\begin{tabular}{|l|c|c|c|c|c|c|c|}
\hline \multicolumn{1}{|c|}{ Country } & $\begin{array}{c}\text { Bangla- } \\
\text { desh }\end{array}$ & Bhutan & India & Maldives & Nepal $\begin{array}{c}\text { Paki- } \\
\text { stan }\end{array}$ & $\begin{array}{c}\text { Sri } \\
\text { Lanka }\end{array}$ \\
\hline $\begin{array}{l}\text { Bangla- } \\
\text { desh }\end{array}$ & 1 & & & & & & \\
\hline Bhutan & $0.5227 * *$ & 1 & & & & & \\
\hline India & $0.4849 * *$ & 0.1295 & 1 & & & & \\
\hline Maldives & 0.0854 & 0.2012 & -0.0412 & 1 & & & \\
\hline Nepal & -0.3293 & -0.0493 & -0.2986 & 0.1546 & 1 & & \\
\hline Pakistan & 0.2979 & 0.1587 & -0.0953 & $0.5360 * *$ & 0.2785 & 1 & \\
\hline Sri Lanka & 0.0881 & 0.1956 & $0.3897 *$ & 0.0486 & -0.2367 & -0.2655 & 1 \\
\hline Range & 4.0157 & 4.0030 & 3.2448 & 4.0123 & 3.9160 & 3.5606 & 4.3899 \\
\hline Minimum & -1.7797 & -2.1808 & -1.8185 & -2.1895 & -1.6956 & -1.2735 & -2.4023 \\
\hline Maximum & 2.2360 & 1.8222 & 1.4264 & 1.8229 & 2.2204 & 2.2871 & 1.9876 \\
\hline
\end{tabular}

(Note) $* *$ and $*$ represent significance at 5 percent and 10 percent levels respectively.

Table 10. Pairwise correlation of demand shocks

\begin{tabular}{|l|c|c|c|c|c|c|c|}
\hline Country & $\begin{array}{c}\text { Bangla- } \\
\text { desh }\end{array}$ & Bhutan & India & Maldives & Nepal & $\begin{array}{c}\text { Paki- } \\
\text { stan }\end{array}$ & $\begin{array}{c}\text { Sri } \\
\text { Lanka }\end{array}$ \\
\hline $\begin{array}{l}\text { Bangla- } \\
\text { desh }\end{array}$ & 1 & & & & & & \\
\hline Bhutan & $0.4094 *$ & 1 & & & & & \\
\hline India & $0.4737 * *$ & -0.0766 & 1 & & & & \\
\hline Maldives & 0.1295 & -0.1540 & 0.2581 & 1 & & & \\
\hline Nepal & -0.0313 & 0.1279 & -0.0502 & 0.1271 & 1 & & \\
\hline Pakistan & 0.2261 & -0.0202 & 0.2257 & 0.3313 & 0.3328 & 1 & \\
\hline Sri Lanka & 0.2980 & 0.0852 & $0.4357 * *$ & 0.0704 & 0.3362 & -0.1049 & 1 \\
\hline Range & 3.8793 & 3.0049 & 2.9384 & 3.5990 & 4.1432 & 3.1257 & 3.5643 \\
\hline Minimum & -1.9314 & -1.3987 & -1.5903 & -1.6581 & -1.6232 & -1.6168 & -1.6565 \\
\hline Maximum & 1.9479 & 1.6062 & 1.3480 & 1.9408 & 2.5201 & 1.5088 & 1.9077 \\
\hline
\end{tabular}

(Note) $* *$ and $*$ represent significance at 5 percent and 10 percent levels respectively. 


\section{Size and speed of adjustment}

As shown in Table 11, Maldives has the largest disturbance to the supply shock followed by Bhutan. They are also the two smallest economies of SAARC in the same order. On the other hand, Nepal has the smallest disturbance followed by Bangladesh and India. Nonetheless, Maldives shows the fastest adjustment to the supply shocks followed by India and Pakistan. Bangladesh and Bhutan are the countries with the slowest adjustment to the supply shock. Further, Maldives also has the largest disturbance to demand shocks followed by Pakistan. Bhutan displays fastest adjustment to the demand shocks followed by Nepal and Sri Lanka. Overall, South Asia responds well in average compare to other regions of the world when considering the results of Bayoumi and Eichengreen (1994), both in terms of size of disturbance and speed of adjustment. The size of disturbance to supply shock is the lowest for South Asia while the disturbance to demand shock is the second lowest following Western Europe. Regarding speed of adjustment, South Asia is the second fastest region to the supply shock followed by East Asia while the region lags behind East Asia and the Americas in terms of speed of adjustment to the demand shock. 
Table 11. Disturbances and adjustment across SAARC Countries

\begin{tabular}{|l|c|c|c|c|}
\hline \multirow{2}{*}{\multicolumn{1}{|c|}{ Country }} & \multicolumn{2}{|c|}{ Supply Disturbance } & \multicolumn{2}{c|}{ Demand Disturbance } \\
\cline { 2 - 5 } & Size & $\begin{array}{c}\text { Speed of } \\
\text { Adjustment }\end{array}$ & Size & $\begin{array}{c}\text { Speed of } \\
\text { Adjustment }\end{array}$ \\
\hline Bangladesh & 0.018 & 0.431 & 0.007 & 0.734 \\
\hline Bhutan & 0.039 & 0.587 & 0.018 & 1.208 \\
\hline India & 0.019 & 1.112 & 0.020 & 0.450 \\
\hline Maldives & 0.042 & 1.145 & 0.050 & 0.506 \\
\hline Nepal & 0.011 & 0.864 & 0.019 & 0.882 \\
\hline Pakistan & 0.024 & 0.924 & 0.039 & 0.706 \\
\hline Sri Lanka & 0.033 & 0.911 & 0.022 & 0.802 \\
\hline SAARC Average & 0.027 & 0.853 & 0.025 & 0.755 \\
\hline Western Europe & 0.030 & 0.684 & 0.022 & 0.417 \\
\hline East Asia & 0.032 & 1.162 & 0.044 & 0.929 \\
\hline The Americas & 0.062 & 0.801 & 0.145 & 0.820 \\
\hline
\end{tabular}

(Note) (i) Figures for Western Europe, East Asia, Europe and The Americas are taken from Bayoumi and Eichengreen (1994), rests are author's calculation.

(ii) ** and * represent significance at 5 percent and 10 percent levels respectively.

\section{Impulse response function}

It is assumed that supply shocks have long term effect on the output and demand shocks have only short term effect on the output. Given that no restriction is imposed on the impact of shocks to the price level, the estimation results are useful in validating the construct of the model. In this regard, the analysis of the impulse response function of the prices to two different shocks can provide important insights. Figure 1 and 2 provide the accumulated impulse response function of prices to supply shocks and demand shocks respectively. Ideally, supply shocks normally decreases price level while the demand shocks increases price level. Based on the analysis of impulse response function, price responds to demand shocks in accordance with the theoretical underpinning. However in the case of response of price to supply shocks, the estimation 
provides opposite results for Bangladesh, Nepal and Sri Lanka while it seems to be more or less neutral for India. For the rest of the other three countries the impact is in accordance with the theoretical construct.

Figure 1. Accumulated impulse response function of prices to supply shocks

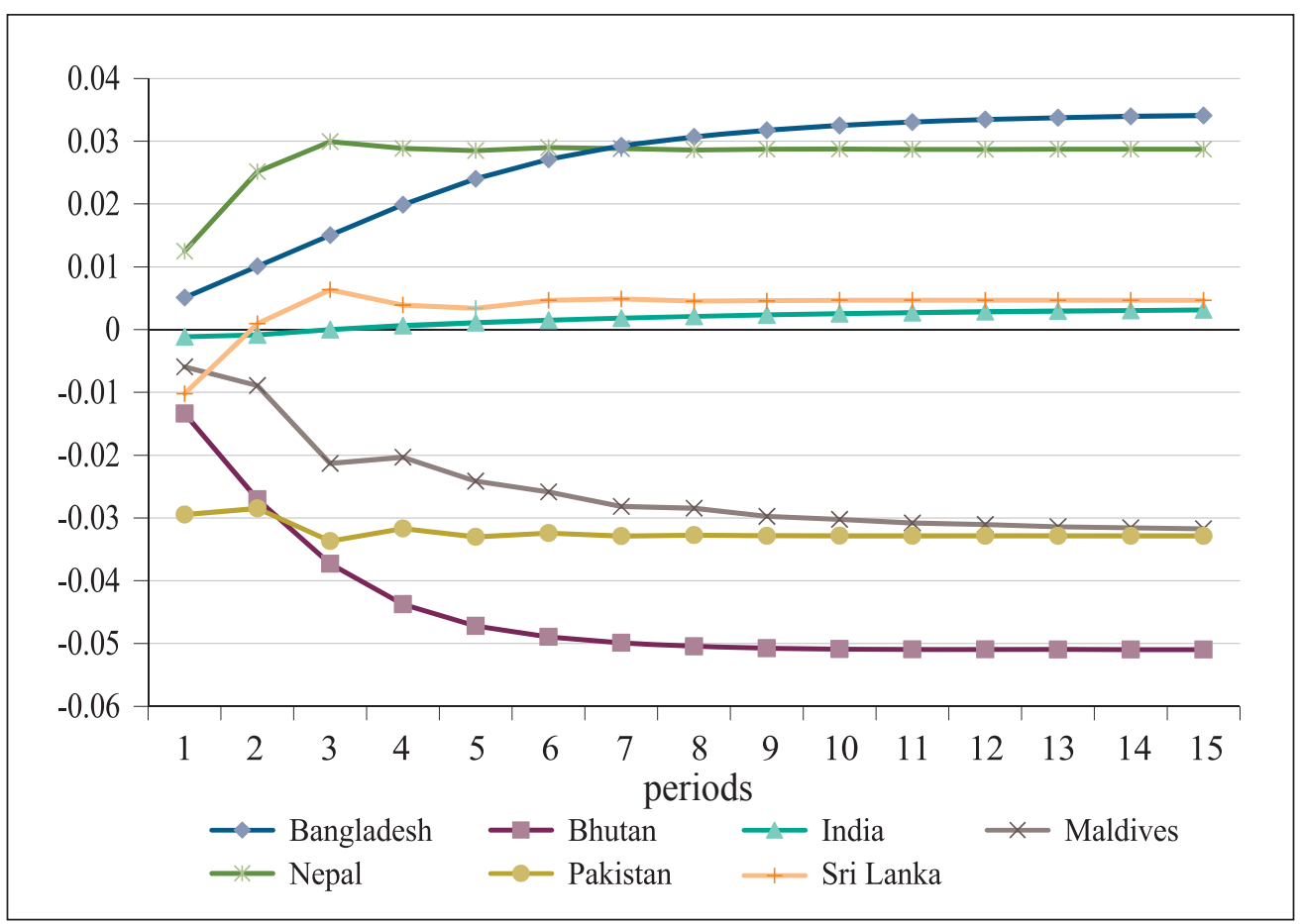


Figure 2. Accumulated impulse response function of prices to demand shocks

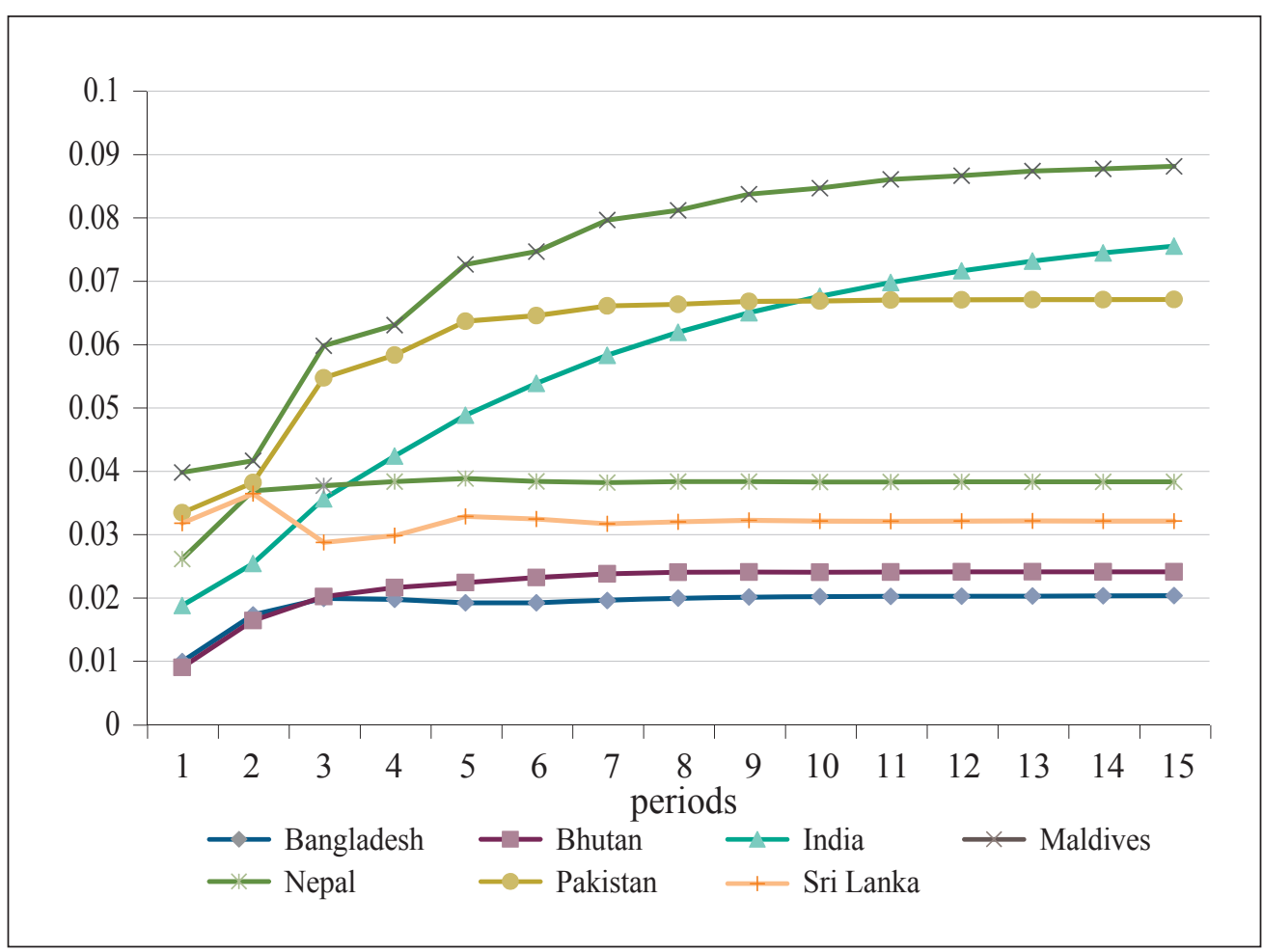

\section{E. Variance decomposition}

Table 12 exhibits the results of variance decomposition of output and price originating from supply shocks and demand shocks over the time horizon of one year, five years and ten years respectively. The fluctuations in output are largely explained by supply shocks for all the countries in the region across all time horizons. The largest difference is between Bhutan and India in the first year where fluctuations in output in the case of India is entirely explained by supply shocks while in the case of Bhutan 68 percent of the output variances are explained by supply shocks. For Bhutan and Maldives, the patterns of shocks explaining output fluctuations remain almost unchanged throughout the entire period. It is interesting to note that only for Bangladesh the proportion of supply shocks increase from 83 percent to 91 percent between first year to fifth year and beyond. In all the other cases, the 
proportion of supply shocks decreases uniformly over the periods marginally except India where the proportion decrease by 17 percent. Furthermore, the patterns of shocks explaining output fluctuations in the fifth year and beyond remain almost the same for each country.

Unlike the output, the results show diverse patterns explaining the changes in price both across countries and time periods. Variation in price in India is entirely explained by demand shocks both in the short term and long term while in Maldives 98 percent in the first year and 90 percent in the fifth year and beyond are explained by demand shocks. In the case of Bangladesh, the proportion evens out in the long run though demand shocks have higher influence in the short run. For Pakistan, the percentage improves in favor of demand shocks from 55 percent in the first year to 60 percent in the fifth year and beyond. On the other hand, proportion of demand shocks decreases from 90 percent in the first year to 80 percent in the fifth year and beyond in the case of Sri Lanka. Bhutan is the only outlier with the changes in price are explained largely by supply shocks and the proportion increases further with time. Similar to output, the variance decomposition of fluctuations in price level exhibits little changes beyond fifth year.

While the results show greater degree of similarity of patterns of shocks in explaining output fluctuations across member nations in South Asia for all time periods, it is less so for price fluctuations. Different structural shocks have varying degrees of impact on the fluctuations of price levels both across the countries in the region as well as over different time periods. 
Table 12. Variance decomposition

\begin{tabular}{|l|c|c|c|c|c|c|c|c|c|c|c|c|}
\hline \multirow{3}{*}{ Country } & \multicolumn{9}{|c|}{ Output } & \multicolumn{5}{c|}{ Price } \\
\cline { 2 - 12 } & \multicolumn{3}{|c|}{ Supply Shock } & \multicolumn{1}{|c|}{ Demand Shock } & \multicolumn{2}{|c|}{ Supply Shock } & \multicolumn{2}{|c|}{ Demand Shock } \\
\cline { 2 - 12 } & 1 & 5 & 10 & 1 & 5 & 10 & 1 & 5 & 10 & 1 & 5 & 10 \\
\hline $\begin{array}{l}\text { Bangla- } \\
\text { desh }\end{array}$ & 82.61 & 90.80 & 91.22 & 17.39 & 9.20 & 8.78 & 24.09 & 44.75 & 48.27 & 75.91 & 55.25 & 51.73 \\
\hline Bhutan & 67.86 & 66.18 & 66.44 & 32.14 & 33.82 & 33.56 & 73.10 & 79.23 & 79.24 & 26.90 & 20.77 & 20.76 \\
\hline India & 98.78 & 82.00 & 81.78 & 1.22 & 18.00 & 18.22 & 0.41 & 0.49 & 0.50 & 99.59 & 99.51 & 99.50 \\
\hline Maldives & 97.16 & 96.35 & 96.32 & 2.84 & 3.65 & 3.68 & 2.27 & 9.87 & 10.12 & 97.73 & 90.13 & 89.88 \\
\hline Nepal & 81.57 & 73.50 & 73.46 & 18.43 & 26.50 & 26.54 & 19.70 & 31.14 & 31.15 & 80.30 & 68.86 & 68.85 \\
\hline $\begin{array}{l}\text { Paki- } \\
\text { stan }\end{array}$ & 87.29 & 81.38 & 81.26 & 12.71 & 18.62 & 18.74 & 45.10 & 39.31 & 39.26 & 54.90 & 60.69 & 60.74 \\
\hline $\begin{array}{l}\text { Sri } \\
\text { Lanka }\end{array}$ & 92.22 & 83.88 & 83.82 & 7.78 & 16.12 & 16.18 & 9.85 & 20.18 & 20.28 & 90.15 & 79.82 & 79.72 \\
\hline
\end{tabular}

\section{Discussion}

The asymmetrical shocks are largely attributed to weak regional economic and financial integration. After the establishment of SAARC, plethora of agreements has been entered aiming at promoting regional cooperation. However, the progress towards actual implementation has so far remained snail-paced. Implementation of agreements, such as SAFTA and SATIS primarily aimed at enhancing regional economic integration through increased intra-regional trade, are very much work in progress.

UNESCAP (2017) estimates that the potential intra-regional export of South Asian countries is three times larger than 2014 export figures and the bilateral trade between India and Pakistan could be 12 times higher than 2014 level. Taneja et al. (2013) also estimates that the potential trade between India and Pakistan is more than 10 times of the 2011 figures. The strained relationship between India and Pakistan and their rivalries have not only adversely affected the bilateral trade but also have constrained necessary reforms for promoting regional cooperation.

The trade cost in South Asia is relatively high because of the issues such as poor connectivity, lack of infrastructure, cross border trade facilitation 
bottlenecks, etc. UNESCAP (2017) estimates that reduction in trade cost by 40 percent from the current level would yield a gain of up to nearly 3 percent in GDP and nearly 11 percent in exports. Similarly, the large amount of informal trade has further undermined the impact on official statistics. In addition, there is no financial integration across countries. The capital markets are fragmented along sovereign markets. All these make South Asia one of the least integrated regions in the world. The empirical results essentially reflect these economic and structural realities.

The SAARC GEP report provides a roadmap for economic integration of South Asia with the establishment of custom union by 2015 and economic union by 2020. The report acknowledges the importance of single monetary system. However, even in the midst of 2018, SAFTA and custom union are far from being achieved let alone the realization of economic union. Single monetary system is even harder to come by. It is very unlikely that the countries in South Asia are ready to give up their own currency. Even if the countries are subject to symmetrical structural shocks and would benefit from forming a monetary union, they are less motivated to undertake such initiatives at this stage. Recent events in Eurozone have exposed the complexities and institutional and policy bottlenecks of managing a monetary union with a single currency.

It is important to focus on more practical mechanism which can promote a monetary integration. In this respect, one can refer the sub-regional integration. The idea of it in SAARC is not new since it began with the launching of BBIN in 1996 comprising of four members, Bangladesh, Bhutan, India and Nepal. A year later, the summit held in Male agreed to address specific challenges of three or more member countries and coordinate efforts at the sub-regional level. South Asia Sub-regional Economic Cooperation (SASEC) Programme which is the initiative of BBIN in 2001 has been extended to include Maldives and Sri Lanka from 2014. Monetary integration can be seen in the same light by exploring the possibility of its implementation at the subregional level.

In fact, the exchange rate arrangements between Bhutan and India as well as Nepal and India mirror Mundell's (1961) version of OCA with fixed exchange rate system. The current bilateral exchange rate frameworks can be expanded to a multilateral monetary framework that can address many constraints. Although Bhutan and Nepal have fixed exchange rate 
arrangements with India, there is no formal bilateral arrangement between them. India has greater role in reforming and advancing current system from merely an exchange rate framework to a broader monetary framework. For example, India is yet to resolve the issue of demonetized higher denomination currency notes that was legally in circulation in Nepal until 8 November 2016. It has created trust deficit against newly introduced higher denominated Indian currency notes in Nepal. The framework can be extended to include Bangladesh (like BBIN initiatives) followed by Sri Lanka and Maldives at the later stage (similar to SASEC project). Pakistan and Afghanistan can decide the opportune time at when to be part of the greater regional monetary cooperation.

It is however interesting to note that the correlation of pattern of shocks among Bhutan, India and Nepal is statistically insignificant. In fact Bhutan and Nepal's share of trade with India as a percentage of their international trade is very large. Even more puzzling fact is India's negative correlation of demand shocks with both Nepal and Bhutan. Bhutan and Nepal also share negative correlation of supply shocks. This result thus raises the efficacy of the endogeneity of the OCA criteria in this sub-regional level. The informal trade between them is also likely to be substantially higher on account of open border.

In the dynamic world, the estimations which are based on purely historical data may not serve as the only guide for the future, known as Lucas Critique. Many empirical studies have shown that the parameters of OCA are largely endogenous and they can be met ex post. The implementation of various agreements under the framework of SAARC that will facilitate movement of people and goods as well as enhance intra-regional trade and investment would hopefully lead to higher synchronization of shocks in the future. The progress towards greater regional economic integration would be central to the process of monetary integration.

Considering all the aspects of monetary integration in South Asia, a phased approach to monetary integration seems both pragmatic and technically viable. Devising a framework that helps the region in moving from literally no monetary cooperation to the greater monetary cooperation would be crucial. In this regard, the central role of India, the largest economy and the most powerful county in the region, should be acknowledged. The concept of Indian currency assuming regional role in terms of the function of money 
such as unit of account, medium of exchange and store of value can be further investigated. Such arrangement is expected to facilitate intra-regional transactions anchored around Indian currency with the aim of achieving greater level of economic, monetary and financial integration. This will allow member states not only the continuation of their national currencies but also permitting them autonomy over their macro-economic policies.

Mintz (1970) argues that political integration is the most important requisite to achieve OCA. Despite meeting all the essential conditions of OCA, it may not see light of the day in the absence of political commitment. While many empirical studies have shown the gains of monetary union outweighing the cost of giving up autonomy over policy and management of exchange rate, the political commitment for such framework is very hard to come by in the context of South Asia. Hence it is necessary to find alternative monetary framework based on political and economic realities of the region.

\section{Conclusion}

The study investigates whether the seven founding members of SAARC constitute an OCA by analyzing symmetry of structural shocks. The increased number of positive correlations of output growth, inflation, exchange rates movement and supply shocks in the last two and half decades compared to earlier studies suggest that there is macroeconomic convergence among the countries. This underpins the basis for moving towards greater monetary cooperation in South Asia in spite of the fact that it is not feasible to pursue a goal of a monetary union with single currency immediately.

In fact there have been a bilateral exchange rate arrangements at the sub-regional level among India and its neighbors Bhutan and Nepal. It fits Mundell's (1961) definition of OCA in terms of exchange rate frameworks though fundamental prerequisites of OCA remain unfulfilled. However, such bilateral exchange rate arrangements can be transformed into multilateral monetary framework that embraces all the three countries. The first step towards greater monetary cooperation in South Asia is to make this multilateral framework work. The suitability of Indian currency as regional currency can be explored in this context.

The positive aspects of such monetary framework are that no nation has to 
give up its national currency, and the region need not confront complexities associated with the adoption of single currency that monetary unions like the $\mathrm{EU}$ is experiencing. The unraveling of Eurozone crisis in recent years has further dampened the spirit and enthusiasm of regional economic blocks for a common currency. Monetary arrangements similar to Common Monetary Area (CMA) of four South African nations (South Africa, Namibia, Swaziland and Lesotho) where the South African Rand serves as a regional anchor are more relevant to South Asia. The system would help in transitioning from current state of almost no monetary cooperation to the greater cooperation which will facilitate greater economic and financial integration.

The deeper economic integration and monetary cooperation can bring about political and financial stability in the region, which is the key to overall development. For SAARC, starting from sub-regional level cooperation with the aim of eventually bringing all the member countries on board can be a possible plan. More studies are required in determining the modus operandi of the monetary system of SAARC.

Received 10 May 2018, Revised 22 August 2018, Accepted 27 August 2018

\section{References}

Bayoumi, T. "The Effects of the ERM on Participating Economies." IMF Staff Papers Vol. 39(2) (1992) : 330-356.

Bayoumi, T., and Eichengreen, B. "One Money or Many," Analyzing the prospects for monetary unification in various parts of the world. Princeton Studies in International Finance 78 (1994). Princeton, NJ: Princeton University International Finance Section.

Bayoumi, T. \& Eichengreen, B. "Shocking Aspects of European Monetary Unification.” In: Torres, F. and Giavazzi, F. (Eds.), Adjustment and Growth in the European Monetary Union, 193-221. Cambridge; Unviersity Press 
Cambridge, 1993.

Blanchard, O. J., \& Quah, D. "The dynamic effects of aggregate and supply disturbances." American Economic Review 79 (1989) : 655-673.

Eichengreen, B., \& Bayoumi, T. “ Is Asia an Optimum Currency Area? Can it become one?" in S. Collignon, J. Pisani-Ferry, and Y. C. Park, eds., Exchange Rate Policies in Emerging Asian Countries. (London: Routledge,1999), 34766.

Engel, C., and Rose, A. K. "Currency Unions and International Integration." Journal of Money, Credit and Banking. (2002).

European Commission (1990). p. 68.

Fleming, J. M. “On Exchange Rate Unification.” The Economic Journal Vol. 81 (1971) : 467-88.

Frankel, J., \& Rose, A. K. "An Estimate of the Effects of Common Currencies on Trade and Income." Quarterly Journal of Economics Vol. 117(2) (2002) : 437-66.

Frankel, J., \& Rose, A. K.. "The Endogeneity of the Optimum Currency Area Criteria." Economic Journal 108 (1998) : 1009-25.

Ingram, J. C. "Regional Payments Mechanisms: The Case of Puerto Rico." University of North Carolina Press. (1962).

Jayasuriya, S., Maskay N. M., \& Weerakoon, D. in collaboration with Khatiwada, Y. R. and Kurukulasuriya, S.. "A Single Currency for South Asia: Economics and Politics of Monetary Integration." Economic and Political Weekly Vol. 40 (29) (2005) : 3159-3166.

.Kenen, P. "The theory of Optimum Currency Areas: An Eclectic View 
in Mundell and Swoboda (eds.) Monetary Problems in the International Economy." University of Chicago Press, Chicago United States. (1969).

Kenen, P. \& Meade E, Regional Monetary Integration, New York: Cambridge University Press, 2008.

Maskay, N. M. "Patterns of shocks and Regional Monetary Cooperation in South Asia." IMF working paper WP/03/240 (2003).

Maskay, N. M. "South Asian Monetary integration in the light of the Optimum Currency Area criteria patterns of shocks.” South Asia Economic Journal 2(2) (2001) : 203-219.

McKinnon, R. I. "Optimum Currency Area." American Economic Review September (1963) : 717-725.

Micco, A., Stein E. H., \& Ordonez, G. "The currency union effect on trade: early evidence from EMU." Economic Policy XXXVII (2003) : 317-56.

Mintz, N. N. "Monetary Union and Economic Integration." The Bulletin, New York University. (1970).

Mundell, R. "Prospects for an Asian Currency Area." Journal of Asian Economics Vol. 14 (2003) : 1-10.

Mundell, R. "A Theory of Optimum Currency Areas." American Economic Review September (1961) : 657-665.

Romano, A., "Applied Statistics for Science and Industry." Boston: Allyn and Bacon Inc (1970)

Rose, A. K. "The Effect of Common Currencies on International Trade: A Meta-Analysis." in V. Alexander, G.M. von Furstenberg, and J. Melitz, eds., Monetary Unions and Hard Pegs, 101-11, Oxford: Oxford University Press, 
2004..

Rose, A. K. "Currency Unions: Their dramatic effect on international trade." Economic Policy (2000b) : 8-45.

Rose, A. K. "One money, one market: estimating the effects of common currencies on trade." Economic Policy (2000a) : 9-33.

SAARC (1997/1998). SAARC Vision Beyond the Year 2000: Report of the SAARC Group of Eminent Persons, p. 20-21.

Saxena, S. C. Can South Asia adopt a common currency. Journal Asian Economics Vol. 16(4) (2005) : 635-662.

Saxena, S. C. (2003). "India's monetary integration with East Asia: A feasibility study." RIS discussion paper RIS-DP, Vol. 64 (2006)

Taneja, N., Mehra, M., Mikherjee, P., Bimal, S. \& Dayal, I. "Normalizing India-Pakistan Trade." In Taneja, N. and Pohit, S. (eds.). India-Pakistan Trade Strengthening Economic Relations, Springer. 13-45.

Tower, E., \& Willet T. (1976). The Theory of Optimum Currency Areas and Exchange Rate Flexibility. International Finance Section No. 11, Princeton University.

UNESCAP (2017). Unlocking the Potential of Regional Economic Cooperation and Integration in South Asia: Potential, Challenges and the Way Forward, United Nations.

Annual Report on Exchange Arrangements and Exchange Restrictions (AREAER) 2016, IMF

Global Human Development Report 2016, UNDP

Direction of Trade Statistics (DOTS) 2017, IMF 
World Development Indicator (WDI), October 2017, World Bank

World Economic Outlook (WEO), October 2016, IMF 